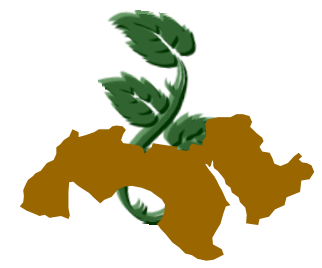

Arab Univ.

J. Agric. Sci., Ain Shams Univ., Cairo, 22(1), 23-28, 2014

\title{
A COMPARISON STUDY ON YIELD AND FRUIT QUALITY OF SOME POMEGRANATE CULTIVARS UNDER ASSIUT GOVERNORATE CONDITIONS
}

\author{
Shadia A. Abdel Hady ${ }^{1}$ \\ 1- Plant Production Dept., Desert Research Center, Cairo, Egypt
}

Keywords: Pomegranate, Yield, Fruit quality

\section{ABSTRACT}

This work was carried out on six pomegranate cultivars namely: Wardy, Araby, Manfalouty , Nab El Gamal, Hhegazy, and Montakhab through two successive seasons grown in a private farm at Assuit government trees were about 13 years and planting distance was $5 \times 5 \mathrm{~m}$. Assuit is governorate considered one of the most important pomegranate producers and exporters in Egypt. The yield and some fruit physical and chemical properties of six different pomegranate cultivars (Punica Granatum L.) were investigated. This investigation aimed to study tree yield and the main fruit characteristics of six commercial pomegranate cultivars. The average fruit yield / tree lies between $38.10-59.90 \mathrm{~kg}$, fruit weight130.96$399.77 \mathrm{~g}$, fruit volume $125.7-520 \mathrm{~cm}^{3}$, fruit diameter 6.23-9.60 c fruit shape index 1.00-1.10 respectively. Fruit dry matter20.49 - 38.57, in addition, total soluble solid content was found between $8.00-16.67$, titratable acidity ranged between 0 . 25- 0.53, TSS / Acid ratio between 0.270.63 , total sugars $9.13-\% 11.86$, reducing sugars $1.22 \%-5.80$, respectively.

Finally it could be concluded that, Manfalouty and Hegazy cultivars recorded most excellent physical, chemical and visual characteristics which are preferred.

\section{INTRODUCTION}

Pomegranate is a highly valued crop and is widely cultivated in Mediterranean countries. It is one of the important fruit of tropical and subtropical regions. Pomegranate (Punica Granatum L.) belongs to the ponicaceae family and is one of the oldest known edible fruits (Pekmezci and Erkan 2003). It is an ideal crop for the sustainability of small holding, as pomegranate is well suited to the topography and agro climate of arid and semi- arid regions, ( Erclls and GAZED 2010 ).

Local pomegranate germplasm collections have been established in several Mediterranean countries, including Spain, Morocco, Tunisia, Greece, Turkey and Egypt (Mars, 2000). In addition, pomegranate trees have great adaptability to adverse climatic conditions, such as saline soil and drought conditions (Seoulveda et al 2000). Assuit Governorate is one of the densest areas as for as pomegranate plantations are concerned. The pomegranate area of Assuit Governorate was estimated to be about 8242 Fadden's produced 58491 Tons M.A.L.R. (2011).

Fruits ripen about 6-7 months after flowering and are harvested when qualities are deemed most appropriatefor expected use (Morton 1987). Minimum maturity for wonderful in California based on titratble acidity less than $1.85 \%$ and color darker than an established reference (Kader 2006). Soluble solids of the cultivars examined did not vary greatly from mid August through mid November and the principal acid was cost malice and citric (Legua et al 2000). It is considered one of the most important fruit of the tropical and subtropical areas because of low maintenance, cost , good yield, good keeping quality and ability to thrive with limited moisture (Indian council of Agricultural research 2005). Mansour (2010) reported that, pomegranates are cultivated in upper Egypt particularly in Assuit, fruit color yellow white to deep dark red. The average yield of a fully grown tree (8-15 years) is 200 fruits varieties: Araby, Manfalouty, Banaty, Hegazy, Balady, Wardy, Yellow, Black and Nabel Gamal. Fruits are found at the market from July till October.

\section{MATERIALS AND METHODS}

This investigation was carried out in a private farm at Assuit Governorate during two successive seasons, 2006 and 2007. Pomegranates (Punica granatum L.) Wardy, Araby, Manfalouty, Hegazy, Nabel Gamal and Montakhab cultivars were used 
for this study. The trees were 13 years old in a state of moderate vigor, rather uniform in shape and size, planting distance was $5 \mathrm{~m}$ apart in clay loam soil. This experiment was arranged in a complete random design including six replicates each of single tree for each cultivar. Fruits of each tree ( in $\mathrm{Kg}$ ) were harvested in bulk at one of the recommended maturity standard outlined by $\mathbf{A h}$ med (1974); Ahmed (1978); El-Kassas (1984); El-Salhy (1985) and Osama (1992). Picking date under the condition of this present was from midAugust through mid November.

To study both physical and chemical fruit properties, 10 fruits were taken from the previously tagged main branches just before harvesting all fruit on each tree fruits were similar in their date of fruit setting. Fruit of each tree cultivar were harvested and taken fruit weight $(\mathrm{g})$ and numbers of fruits per tree were determined.

The yields $(\mathrm{Kg} / \mathrm{tree})$ in each replicate for each cultivar under study were recorded for each cultivar. All fruit samples were tested for average fruit weight, fruit volume, fruit length, fruit diameter , and fruit shape index. Fruit dry matter percentage and total soluble solid (TSS) as percent are determined by a hand refractometer. Total acidity as percent, was estimated as critic acid, by titrating of $0.1 \mathrm{~N}$ Sodium Hydroxide against $5 \mathrm{ml}$ juice using phenolphthalein as an indicator Maturity index was expressed as total soluble solid / acid ratio. Reducing and total sugar percentage were determined in Juice according to the method of ( lane ) and ( Eynon) as discriped in the A.O.A.C. (1975). Statistical analysis was carried out according to (Sendecor and Cochran, 1980). Tree Means were Compared using L.S.D. Values at 0.05 level.

\section{RESULTS AND DISCUSSION}

Data in Table (1) showed yield, fruit weight, fruit volume, fruit length and fruit diameter of some pomegranate cultivars under Assuit governorate conditions in 2006 and 2007 seasons.

\section{Yield / tree $(\mathrm{Kg})$}

Highest significant values were recorded by Manfalouty and Hegazy cultivars in both seasons.

\section{Fruit weight}

Manfalouty cultivars had highest significant fruit weight in both seasons.

\section{Fruit volume}

In both seasons highest significant fruit volume was recorded by Manfalouty cultivar.

\section{Fruit length}

In the first season Nabel Gamal gave higher significant value than most of other cultivars.

In the season second season Manfalouty showed higher significant value than most of other cultivars.

\section{Fruit diameter}

Higher significant value was noticed by Manfalouty than most of other cultivars in the first season, but in the second season Manfalouty and Hegazy had higher significant values than first and last cultivars.

\section{Fruit shape index}

Insignificant differences could be noticed among cultivars in both seasons.

Data in Table (2) showed the fruit dry matter percentage, total soluble solid percentage , TSS / Acid ratio, total sugar percentage and reducing sugar percentage of some pomegranate cultivars under Assuit governorate conditions in 2006 and 2007 seasons.

\section{Fruit dry matter percentage}

In the first season Montakhab cultivar showed highest significant value but in the second season insignificant differences could be noticed among cultivars.

\section{Total soluble solid percentage}

Wardy cultivar had higher significant value than Araby and Nab el Gamal in the first season. In the second season Montakhab gave higher significant value than most of other cultivars.

\section{Acidity \%}

Montakhab cultivar recorded highest significant value in the first seaon. The second season Araby and Hegazy cultivars had recorded lowest significant values.

\section{TSS / Acid ratio}

Wardy and Hegazy cultivars showed higher significant value than Araby and Nab el Gamal in the first Season. In the second season Hegazy cultivar had higher significant value than Araby and Nab el Gamal cultivars.

\section{Total sugar percentage}

Montakhab cultivars recorded showed insignifi- 
Yield and fruit quality of some pomegranate cultivars under Assiut governorate conditions 25

cant value in both seasons.

Arab Univ. J. Agric. Sci., 22(1), 2014 
Arab Univ. J. Agric. Sci., 22(1), 2014 


\section{Reducing sugar percentage}

In the first season Wardy and Araby cultivars gave lowest significant value than Montakhab. In the second season Montakhab cultivar had lowest significant value.

Date in Table (3) showed that peel color, fruit shape and kernel color some pomegranate.

\section{Peel color}

Montakhab and Hegazy recorded preferred peel color more than other cultivars.

\section{Fruit shape}

Fruit round shape conceder preferred fruit shape which noticed by all fruit cultivar except Araby and Montakhab.

\section{Kernel color}

Dark red color kernel recorded by Manfalouty and Hegazy.

Finally it could be concluded that, Manfalouty and Hegazy cultivars recorded most excellent physical, chemical and visual characteristics which are preferred.

Table 3. Peel color, fruit shape and kernel color of some pomegranate cultivar under Assuit governorate conditions in 2006 and 2007 seasons:

\begin{tabular}{|lccc|}
\hline \multicolumn{1}{|c}{ Varity } & Peel color & Fruit shape & Kernel color \\
\hline Wardy & Yellow red & Rounded & Dark pink \\
Araby & Light yellow & Slatted & Light red \\
Manfalouty & Pink red + dark red & Rounded & Dark red \\
Hegazy & Pink red + dark red & Rounded & Dark red \\
Nabel-Gamal & Red yellow & Rounded & Red \\
Montakhab & Light pink & Slatted & Light yellow \\
\hline
\end{tabular}

\section{REFERENCES}

Ahmed, A.M. (1974). The Effect of Some Fertilizer Treatments on the Yield and Quality of some Varieties of Pomegranates. M.Sc .Thesis, Fac. of Agric, Assiut Univ., Egypt.

Amoros, A., Jo. P., Melgare J.J. Marinez Hernandez F. and Mortinez M. (2000). Characterization of the fruit of five pomegranate ( Punica Granatum $L$ ) clones cultivated in homogeneous soils. Options Méditerranéennes ser. A 42:129-135

Association of Official Agricultural Chemists. (1975). Official Methods of Analysis A.O.A.C. $1^{\text {th }}$ Ed. Published by A.O.A.C. Washington, D.C.U.S.A.

Bist, H.S., Srivastava R. and Sharma G.S. (1994). Variation in some promising selection of wild pomegranate (punica granatum $L$ ) Hort. J. 7:67-70

Costa, Y.P. Melgarejo (2000). A study of the production costs of tow pomegranate varieties grown in poor quality soil options Méditerranéennesser. A 42:49-53.

EL-Kassas, SH. E. (1984). Seasonal changes in growth and nutrition of Manfalouty Pomegranate fruits under certain soil moisture levels. Assiut J. Agric. Sci., 15(1): 81-92.
El-Kassas, S.E., Elsise A.M., EL-Salhy A.M. and Abadia A.M. (1998). Bearing habits in some pomegranate cultivars. Assuit J. Agr. Sci. 29: 147-162.

EL-Salhy, A.M. (1985). Fruiting of Manfalouty Pomegranate as Influenced by Some Growth Regulators. M.Sc. Thesis, Fac. of Agric., Assiut Univ. , Egypt.

Erclls S. and Gadze J. (2010). Proizvodnjasipka u Turskojhrvatskoj. Ubhrvatski ib. medumarodnisimpozijagronoma. Zborniksazetaka pp. 298299.

Gozlekci, S. and Kaynak L. (2000). Investigations on pollen production and quality in some standard pomegranate ( Punica Granatum $L$ ) cultivars. Options Méditerranéennes Ser. A 42: 71-77.

Kader, A.A., Heber D., Schulman R.N. and Seeram N.P. (2006). In pomegranate: Ancient roots to modern medicine, postharvest biology and technology of pomegranates, edsseeram N.P., Schulaman R.N., Heber D. (CRC Press, Boca Raton, FI), PP. 211-220.

Kher, R. (1999). A note on the physic - chemical characters of the wild pomegranate ( punica protopunica $L$ ). Ann. Biol Ludhiana 15:321232 . 
Larue, J.H. (1980). Growing pomegranates DANR publication 2459. Leaflet.

http://fruitsandnuts.ucdavis.edu/crops/pomegra natefactsheet.shtml\#b. 1 Sept. 2006.

Legua, P., Melgarejo P., Martinez M. and Hermandez, F. (2000). Evolution of sugars and organic acid content in three pomegranate cultivars (Punica Granatum L). Options Mediterranean's ser. A 42: 99-104.

Mansour, K.M. (2010). Underutilized fruit crops in Egypt Horticultural Research Institute. Agriculture Research center Ministry of Agriculture, Egypt.

http://www.docstoc.com/docs/24842361/Un derutilized-fruit-crops-in-Egypt.

Mars, M. (2000). Pomegranate plant material: Genetic resources and breeding, a review options Méditerranéennes Ser. A 42:55-62.

M.A.L.R. (2011). Ministry of Agriculture and land reclamation, central administration of agriculture economics. Egypt. Agricultural Statistics.http://aces.nmsu.edu/pubs/foreigntechn ology/docs/HamdyVitae.pdf.

Morton, J. (1987). Fruits of warm climates (Miami, F1). 33189 ISBN:0-9610184-1-0 Distributed by
Greative Resource systems. Inc. Box 890. Winterville.N.C. 28590.

Indian council of Agricultural Research (2005). Power inaugurates news national research center on pomegranate. www.icar.org.inpr/25092005. htm. 1 Sep. 2006.

Osman, S.M. (1992). Effect of Certain Methods of Weed Control And Nitrogen Fertilization on The Yield, Fruit Quality and Some Nutrient Contents Of Manfalouty Pomegranate Trees. M.Sc. Thesis, Fac. of Agric, Assiut Univ., Egypt.

Pekmezci, M. and Erkan M. (2003). Pomegranate in: Gross (ed). Postharvest quality maintenance guidelines. USDA, Agriculture Research service handbook N. 66.

Http://www.egraphx.com/PHYTOCEUTICALS.pdf

Seoulveda, E. Galletti; Seanz C. and Tabia M. (2000). Mini mal processing of pomegranate var. Wonderful ci HEAM OPTIONS Mediterranean's, 42: 237-242.

Snedecor, G.W. and Cochran W.G. (1980). Statistical Methods $6^{\text {th }}$ Ed. Theiowa State Univ. Press. Ames. lowa U.S.A. 